\title{
'N DIALOGIESE KOMMUNIKASIETEORIE VANUIT 'N PRAKTIES-TEOLOGIESE PERSPEKTIEF
}

\author{
H J C PIETERSE
}

\begin{abstract}
A dialogical theory of communication from a practical theological perspective

For our practical theological reflection on the communication of the gospel in ministry, we need a sound theory of communication. We choose for a dialogical theory of communication which suits the nature of Christian communication. This theory is developed with insights from theology and philosophy. The roots of a dialogical theory of communication are found in the thoughts of Socrates, Plato en Augustine. Kierkegaard is seen as the founder of the modern dialogical theory of communication, whilst the contributions of Buber, Jaspers, Gadamer and Habermas are traced. In an era of mass communication and propaganda. Christians need a communicative context where dialogue, freedom and an existential experience of God's love and grace can develop.
\end{abstract}

\section{Inleiding}

$J$ Firet het by sy afskeid as professor in Praktiese Teologie aan die Vrije Universiteit in Amsterdam opgemerk dat daar één ding is wat in die laaste jare in die ontwikkeling van die vak uitgekristalliseer het, naamlik 'n groeiende konsensus dat dit in die Praktiese Teologie om kommunikatiewe handelinge in diens van die evangelie gaan. Die dienswerk van die kerk in al sy vertakkinge behoort dus vanuit die perspektief van die kommunikasie van die evangelie bestudeer te word. Die Woordgebeure in die werklikheid van die lewe van die gemeente is wesenlik kommunikatief.

Hierdie kommunikatiewe handelinge is sinvol (vind sin) vanweë die gebeure waarin God in sy Woord tot die mens in sy wêreld kom deur die spesifieke (pastorale) kommunikatiewe handelinge van mense as intermediêr. Met die perspektief op ons vak dat dit ' $n$ kritiese teologiese handelingswetenskap is, wat kommunikatiewe handelinge bestudeer met die oog op die oordrag en onderhouding van die Christelike geloofspraxis, plaas ons die vak binne die raamwerk van die moderne wetenskapsdenke.

Indien kommunikatiewe handelinge in diens van die evangelie die objek van ons vak is, is dit uiters belangrik om met ' $n$ duidelik uitgespelde 
kommunikasieteorie te werk. Die perspektief, die benadering tot ons studieveld is wesenlik geloofskommunikasie tussen mense. Ons moet uit die talle kommunikasieteorieë ' $n$ teorie kies en verfyn wat gepas is vir ons vakgebied. Ons werk met interpersoonlike kommunikasie en so 'n teorie as ideaal moet ons in ons wetenskaplike werk rig. Dit kan ook rigtinggewend funksioneer in die praktyk van die kommunikatiewe handelinge in diens van die evangelie. Aan die keuse van so ' $n$ teorie wil ons hier aandag skenk.

\section{Kriteria vir die keuse van 'n kommunikasieteorie}

In die keuse van 'n kommunikasieteorie moet ons ons laat lei deur kriteria wat die gepastheid van so 'n teorie binne die kommunikasiepraktyk van die Christelike gemeente na vore sal bring. Daar is talle dissiplines wat die kommunikasieverskynsel bestudeer, elk vanuit 'n eie perspektief. Uiteraard bestudeer ons die kommunikasieverskynsel binne die Christelike gemeente (en die interaksie van die gemeente met die samelewing) vanuit ' $n$ teologiese perspektief. Die feit van die kommunikatiewe handelinge in diens van die evangelie vra dus na 'n teologiese vertolking. 'n Kommunikasieteorie wat onderliggend aan ons kommunikatiewe handelinge is, sal dus sy wortels in ons teologiese tradisie moet hê. Ons kan dit fundeer in God se kommunikasie met ons in die openbaring wat in die Bybel aan ons oorgelewer is. Al die openbarende woorde en dade van God aan ons is wesenlik kommunikatief. Die diepste grond hiervan is egter die menswording van Jesus Christus. Dit is die teologiese basis van ons kommunikasieteorie. Hy is die hoogtepunt en die eindpunt van God se openbaring aan ons.

Trou aan die aard van ons vak sal ons teorie egter ook ' $n$ ander komponent - naas die teologiese - moet hê. Ons sal dus by die gedagtes van groot denkers oor kommunikasie deur die eeue heen gaan kers opsteek. Omdat kommunikasie teoreties van verskeie gesigspunte benader word (soos bv. die media in die proses; die omstandighede waaronder gekommunikeer word; en die mense wat kommunikeer), sal ons vanuit ons eie kommunikasiekonteks kriteria aanlê vir die keuse van hierdie komponente vir ons teorie. Ons sal nie eklekties te werk gaan nie, maar trag om by ' $n$ bestaande teorie aan te sluit.

Belangrike kriteria word verskaf deur wat ons kan noem koninkrykswaardes. Die koninkryk waarvan hier sprake is, is die koninkryk van God wat as ideale kommunikasiesituasie in ons denke funksioneer. Hierbinne geld eerstens 'n nie-outoritêre kommunikasie. Mense moet as vrye subjekte op gelyke voet met mekaar kan kommunikeer. Die dialoogrolle moet prinsipieel wisselbaar wees. Elke persoon 
moet ' $n$ gelyke kans hê om in elke fase van die proses handelend op te tree.

Tweedens veronderstel kommunikasie binne die ryk van God 'n onvoorwaardelike vryheid by die deelnemers. In die sfeer van die evangelie is geen dwang nie. Elkeen is vry om self oor ' $n$ saak te besluit en in eie verantwoordelikheid tot ' $n$ besluit te kom. Dit beteken dat elkeen die ander se vryheid erken en aan hom/haar toestaan, en in solidariteit as vrye subjekte kommunikeer.

Derdens geld ' $n$ onvoorwaardelike aanvaarding van die ander as volwaardige mens en 'n erkenning van die ander se reg op 'n outentieke bestaan.

'n Kommunikasieteorie wat ten grondsiag lê van kommunikatiewe handelinge in diens van die evangelie, sal dus die toets van die koninkrykswaardes moet deurstaan. Saam met C Bäumler kan ons die koninkryk van God sien as die ideale situasie van vrede, geregtigheid, vryheid en heil.

'n Verdere kriterium vir die keuse van ' $n$ teorie is ons antropologie. Die Bybel verskaf nie ' $n$ sistematiese antropologie nie. Dit verskaf eerder ' $n$ vertikale beligting. Daarom moet ons die mens van ons tyd in Bybelse perspektief sien. Hierin volg ons die metode waarin die insigte van die menswetenskappe, in hierdie geval die filosofie, en die teologie op mekaar betrek word.

Die mens is deur God geskep. Hierdie geloofsuitspraak op grond van die Skrif dui die wesenlike betrokkenheid van die mens op God aan. Alle mense is kragtens die skepping in ' $n$ verband met God geplaas. Die mens is kreatuurlik as geskapene ' $n$ swakke en beperkte wese, maar tog selfstandig. Die mens het 'n afhanklike selfstandigheid.

Die selfstandigheid beteken dat die mens as ' $n$ unieke persoon, as 'n "ek" geskape is. Die mens het 'n sekere vryheid en hy/sy kan keuses maak en so die eie bestemming bepaal. Daarom is die mens ten volle verantwoordelik vir sy/haar keuses.

Die mens is as ' $n$ vrye, unieke en selfstandige persoon na die beeld van God geskep. Dit bepaal die áárd van die mens se bestaan: dat hy/sy God se verteenwoordiger op aarde is en verantwoordelikheid dra vir die skepping; dat hy/sy aangelê is op God en bestemming vind in samesyn met God en mekaar; dat hierdie aangelê wees op God beteken dat die mens onderweg is - die mens is ' $n$ wese wat wôrd; dat hierdie op-wegwees, hierdie wording in die rigting van sy bestemming, beteken dat die mens in verhoudinge staan en só sin vind - met God, met mekaar en met die natuur. In sy selfverwerkliking is die mens aangewese op ' $n$ lewe in sinvolle verhoudinge wat onderlinge begrip en gemeenskap bewerk, waarsonder geen mens kan bestaan nie. 
Omdat die mens in soveel verwikkelde verhoudinge staan, moet ons ' $n$ totale of holistiese blik op die mens hê. Die mens word vandag in die menswetenskappe as ' $n$ eenheid gesien. Dit is ' $n$ groot fout om die mens net as ' $n$ "siel" te sien, of as ' $n$ biologiese eenheid, of as net ' $n$ politieke wese. Die mens moet holisties gesien word binne sy/haar politieke, sosiale, kulturele en ekonomiese situasie.

Die mens se bestaan is geworpe in pyn, lyding, onvolmaaktheid, stryd, onderdrukking en geweld. Dit is 'n bestaan in pyn. Ook dit moet in ' $n$ vertikale lig gesien word: die sonde het ons verderf. Die mens leef egter in hoop. En die beste hoop vir die mens is die bevrydingsboodskap in die evangelie van Jesus Christus. Deur geloof in Christus kan die mens en sy samelewing in beweging kom om dinge reg te stel in die lig van die herskepping in Christus. Die herskepte mens vind ' $n$ nuwe humaniteit wat in haar/hom gevorm word na die beeld van Jesus Christus. Sonder 'n grondige antropologie kan ons nie 'n gepaste kommunikasieteorie in die visier kry nie.

'n Laaste kriterium wat ons wil noem, is die vraag of die kommunikasieteorie wat ons kies in so ' $n$ mate in diens van die evangelie kan staan dat die evangelie as heilsgebeure in mense se lewens kan geskied. Die teorie moet 'n teorie wees wat die moontlikheid bied vir die lewende gebeure van 'n ervaring met God vanweë die kommunikasiegebeure. Dit mag dus geen geslote teorie of model wees wat geen ruimte vir die metafisiese laat nie. Kortom, ons soek 'n teorie wat óóp is - horisontaal en vertikaal. Dit moet ruimte bied vir 'n egte en waaragtige ontmóéting tussen mense en tussen mense en God.

In die lig van bogaande kriteria kies ons vir 'n dialogiese kommunikasieteorie. Ons sal nou die ontwikkeling van hierdie teorie, wat soos 'n goue draad in die denke van verskeie mense deur die eeue loop, op die voet volg.

\section{Sokrates, Plato en die dialoog}

In Sokrates (469-399 v.C.) het ons te doen met een van die grootste geeste van die filosofie. Vir ons doel is sy groot bydrae sy metode van die dialoog om die waarheid te ontdek. Sy werkplek was die markplein waar hy deur die dialoog heen na die goeie en die ware gesoek het. Hy het mense deur sy vrae en deur die gesprek heen gelei om sélf in te sien wat onwaar was en wat waar, reg en goed was. Dit was ' $n$ indirekte kommunikasie waarin niemand tot ' $n$ standpunt gedwing is nie, maar gestimuleer is om selfstandig tot insig in die waarheid te kom.

By Sokrates het ons alreeds die kritiek op die welsprekende burgers van Athene gehad en die ontwikkeling van die dialogiese metode van 
kommunikasie. Plato ( $427-347$ v.C.), wie se talryke geskrifte byna alles vir ons bewaar gebly het, het die dialoog tot teorie en praktyk uitgebou. Die aanleiding tot sy dialogiese kommunikasiewyse was sy kritiek op die bestaande kommunikasiepraktyk van die retoriek.

Plato se kritiek was gerig teen die misbruik van oorreding in die retoriek. Dit was 'n soort direkte kommunikasie waarin mense tot die standpunt van die spreker oorgehaal is en nie genoeg ruimte gehad het om selfstandig tot insig te kom nie.

In kommunikasie gaan dit, volgens Plato, ook om die etiese en die ideale bestaan. Die lewe is 'n soeke na regverdigheid, die skone en die goeie. Die lewe is as sodanig dialogies en die bestaan word in dialogiese kommunikasie gerealiseer. Plato deklameer nie sy gedagtes nie, maar bring dit indirek in 'n gesprek na vore. Die ontvanger se rol is deurslaggewend. Sonder sy/haar aktiewe deelname is daar geen kommunikasie nie. In die dialoog is die deelnemers dus op gelyke voet. Die dialoog is 'n oop gesprek en dit geskied by wyse van twee komplementêre stappe: die elenktiek, of die kuns van weerlegging, en die maieutiek, of geestelike verloskunde. Met die eerste stap word die skynkennis ontmasker en met die tweede stap word ' $n$ juister insig in die plek daarvan gestel. Die Platoniese dialoog verskil dus van die gewone gesprek vanweë bogenoemde twee stappe wat dit inhou.

Ons merk dus dat in die dialogiese opvatting van Sokrates en Plato daar ' $n$ paar aspekte is wat ons kan sistematiseer: die dialogiese alternatief ontwikkel vanweë kritiek op die heersende kommunikasiewyse; dit is 'n indirekte kommunikasiewyse waarin die gespreksgenote selfstandig tot insig van die waarheid kom - dit geskied dus met vryheid van die deelnemers; die ontvanger $k r y$ ' $n$ belangrike plek en die gespreksgenote staan op gelyke voet teenoor mekaar.

\section{Augustinus as oorgangsfiguur}

Aurelius Augustinus ( $354-430$ n.C.), daardie groot seun van Afrika, is 'n soort oorgangsfiguur wat dialogiese kommunikasie aanbetref tussen die klassieke denke en die moderne insigte van die kommunikasiekunde. Net soos Sokrates en Plato leef hy ook in 'n krisistyd waarin die politieke, sosiale en ekonomiese stelsels van sy tyd vernietig word en daar groot onsekerheid is oor die tcekoms. Sulke tye laat 'n mens dink.

Dit is nie verbasend dat Plato Augustinus se denke so sterk beïnvloed het nie. Augustinus was ' $n$ retor en deurdrenk van die klassieke geleerdheid. Die gedagtes van Plato oor ons onderwerp het beslis ook Augustinus se denke bevrug.

$\mathrm{Na}$ sy bekering in 386 n.C. het hy gekommunikeer met die doel om 
mense - ook die massa - tot die Christendom te bekeer. Sy doel was dat hulle deur sy kommunikasie die goddelike Waarheid, Jesus Christus, sou ontmoet. In die nastrewe van hierdie doel het hy die grense van die dialoog verskuiwe tot buite die beperkinge van interpersoonlike kommunikasie (in die sin van één persoon tot 'n ander persoon) deur sy prediking en sy geskrifte. Want ook in sy prediking en sy skryfwerk bly hy dialogies en persoonlik.

Die "waarheid" by Sokrates en Plato kry dus 'n spesifieke inhoud by Augustinus, naamlik Jesus Christus. Alhoewel hy 'n geesdriftige kommunikeerder hiervan is, laat hy dit op dialogiese wyse blyk, hoop hy dat dit aantreklik is en laat hy die ontvanger vry om dit self te aanvaar op sy/haar eie wyse.

Augustinus bied belangrike insigte oor die verstaansproses in dialogiese kommunikasie. Hy het by Ambrosius geleer om die Bybel stil in plaas van hardop te lees en op dié wyse te soek na die betekenis en waarheid van die Skrif. Die Waarheid wat hy ontdek het, het sy afkeer van die plat taal van die Bybel oorwin. Op hierdie wyse het Augustinus die kultuurskat van die Grieks-Romeinse beskawing binne die Christendom behou. Die stil lees van ' $n$ geskrif het hom gelei tot die insig dat daar by die mededeling en ontvangs van boodskappe twee aparte verstaansprosesse afspeel. Die ontvanger moet die boodskap verwerk totdat dit vir hom/haar sinvol is. Die mededeler moet sy insigte onder woorde bring, wat soms moeilik is om met presiesheid te doen. Die doel van kommunikasie - spesifiek van die Woord van God - is onderlinge begrip tussen mededeler en ontvanger. Hierdie begrip word moontlik in die konteks van die Christelike geloof deur die innerlike verligting en onderrig van Christus self. Daar is dus ook ' $n$ vertikale element in die Christelike kommunikasie wat begrip bevorder en mense lei in die rigting van verstaan en 'n sinvolle Christelike bestaan.

Die ontvanger is uiters belangrik vir Augustinus. Die ontvanger moet selfstandig tot begrip en insig kom. Soos hyself in sy Belydenisse worstel met die vraag vile hy is, laat hy die ontvangers van sy mededelings toe om tot insig te kom. Hy gebruik eenvoudige taal om die diepste gedagtes oor te dra en wend retoriese beginsels aan om sy hoorders te help om te verstaan. Die ontvanger is dus vertolker en moet ook mededeler word, want die evangelie moet uitgedra word.

Uit sy aanwysing vir die prediking en uit sy Belydenisse blyk sy antropologie. Die mens is ' $n$ subjek wat nie soos ' $n$ objek gemanipuleer mag word nie. Die mens is ' $n$ unieke individu en moet as individu gerespekteer word. Die mens is in wording, op soek na die eie self. Die mens se hart is rusteloos totdat dit rus vind in God. In sy Belydenisse lê hy homself bloot aan almal om te sien - dit is eksistensiële kommunikasie 
soos die moderne tyd dit eers weer sou ontdek.

Augustinus het die dialoog as instrument in interpersoonlike kommunikasie - ook in ' $n$ breër konteks soos die prediking - behendia gebruik. Hy bied ruimte vir sy gespreksgenote en bied vryheid tot selfstandige insig en begrip. Sy kommunikasie-insigte bied egter 'n uitbreiding op dié van Sokrates en Plato: hy behandel die dialogiese in die konteks van groter groepe mense met wie deur 'n mededeler gekommunikeer word (die prediking); hy bou 'n vertikale dimensie in op die horisontale vlak van kommunikasie wat vir die kommunikasie van die kerk uiters belangrik is; en hy bied ' $n$ mensbeskouing wat dit vir elke deelnemer moontlik maak om op sy/haar manier die ander te verstaan.

\section{Soren Kierkegaard, grondlegger van die moderne dialogiese kommunikasieteorie}

Marthinus van Schoor beskou Kierkegaard (1813-1855) as die grondlegger van die kommunikasiekunde van die 20 ste eeu. Kierkegaard het ' $n$ hele filosofiese sisteem ontwikkel waarop ons nie hier kan ingaan nie. Sy insigte in kommunikasie lê ook verweef in sy filosofie. Vanweë die groot omvang en ingewikkeldheid van sy geskrifte en sy denke sal ons volgens die interesse van hierdie opstel net dié dinge uitlig wat vir ons doel belangrik is.

Kierkegaard het gevoel dat die kommunikasie van die pers en die kerk van sy tyd onbevredigend was. Sy insigte het ontstaan vanweë sy kritiek op hierdie onbevredigende kommunikasie.

Die kern van Kierkegaard se kommunikasie-insigte wentel om sy siening van die self en die mens. Sy groot vraag, volgens Nerina Jansen, was wat dit beteken om te bestaan, dit is, wat dit beteken om 'n Christen te word. Die enkeling is die wordende Christen wat homself/haarself deur kommunikasie met God vind en tot die hoogste moontlike mate in kommunikasie met sy medemens verwesenlik. Kierkegaard se drie bestaansfere (die estetiese, die etiese en die religieuse) bied ' $n$ oorsig oor al die bestaansmoontlikhede waarin die mens probeer om homself/haarself deur kommunikasie te verwesenlik. Elke bestaansfeer is 'n stap op weg na selfwording en selfverwesenliking. Kierkegaard sien die mens as wordende waarin die mens se hele bestaan ' $n$ bewuswording en verwesenliking van die self is. Die mens se eksistensiële taak is om te word wat hy uiteindelik moet wees.

Binne hierdie antropologie moet sy siening van bestaan, eksistensie, en sy eksistensiële of bestaanskommunikasie gesien word. Eksistensie is vir Kierkegaard die gehalte van die individuele lewe, wat te midde van omstandighede wat die enkeling wil massifiseer en tot één standpunt 
dwing, ' $n$ persoonlike en outentieke stempel op sy omstandighede moet afdruk. Die mens moet kom tot ' $n$ eie, selfstandige keuse en besluit oor sy/haar lewe en 'n eie outentieke bestaan voer in eie verantwoordelikheid. Dit kan bereik word in kommunikasie met God en die medemens. In hierdie kommunikasie gee die mededeler sigself in subjektiewe betrokkenheid aan die gespreksgenote. Die mededeler moet eksisteer in sy/haar mededeling - hy/sy moet wees wat hy/sy meedeel. Net so moet die ontvanger van die mededeling in sy/haar vertolking eksisteer.

Kierkegaard werk in sy kommunikasie met die dialogiese begrip. Kommunikasie moet ' $n$ egte dialoog wees tussen twee of meer vrye, selfstandige subjekte. Daarom staan sowel mededeler as ontvanger op gelyke voet. Die ontvanger is die keerpunt. Die dialoogrolle kan prinsipieel omgeruil word.

Kierkegaard het nie aan direkte kommunikasie geglo nie. Kommunikasie moet indirek wees. Die mededeler moet die keuses aan die ontvanger voorhou en hom dan uitlok om selfstandig en op eie wyse die mededeling te vertolk, tot ' $n$ eie besluit te kom en in die rigting van selfverwesenliking te beweeg. Hierdie keuses lê wesenlik tussen tydelike en ewige, oneindige en eindige, noodsaak en vryheid. Die self is ' $n$ sintese tussen hierdie pare teenoorgesteldes. Die mens moet voortdurend kies tussen hierdie elemente.

Kierkegaard se kommunikasie is Christelik gestempel. Daarom is die hoogste bestaansfeer en die diepgaandste kommunikasie religieus. Kommunikasie van die Christelike geloof geskied ook só dat die prediker hoogstens die ontvanger kan uitlok, die teenstrydighede en die keuses uitwys, en so die ontvanger aktiveer. Die toe-eiening van die boodskap moet deur die enkeling self subjektief deurleef word in ' $n$ persoonlike verhouding met God.

In die kommunikasie tussen mens en mens op gelyke voet, met inagneming van die gesagvolle spreke van God in sy kommunikasie met ons, kan ons sáám strewe na onderlinge begrip. Want onderlinge begrip oor die betekenis van ons bestaan en ons bestaan met God en met mekaar, gee uiteindelik sin aan ons kommunikasie.

In die werk van Kierkegaard vind ons weer die lyn wat van Sokrates af loop: die dialoog as alternatief op dwangmatige massakommunikasie; gespreksgenote wat in vryheid en op gelyke voet in hul kommunikasie streef na onderlinge begrip en bestaansverwesenliking; ' $n$ mensbeskouing wat outentiekheid, vryheid en selfstandigheid in die hand werk; en ' $n$ hoogagting van die ontvanger as ' $n$ kernfaktor in die proses. Kierkegaard het egter hierdie gedagtes op ' $n$ diepsinnige wyse in die konteks van die 19de eeu uitgewerk. Sy denke het die 20 ste eeu diepgaande beinvloed. 


\section{Twintigste-eeuse denkers oor die dialogiese kommunikasieteorie}

In hierdie eeu het die mens se outentieke bestaan, waaroor Kierkegaard

- dit gehad het, onder groot druk gekom. Die industriële en tegnologiese ontwikkeling het reusagtige stede en hoogs georganiseerde gemeenskappe geskep waarin die mens 'n nommer, 'n deel van die massa geword het. Hierdie onpersoonlike tendens is versterk deur die massakommunikasie waarin kommunikasie op 'n gemiddelde soort mens gerig is. Die plek van die enkeling, Kierkegaard se deurslaggewende faktor, het haas verlore gegaan in die massamening en massa-optrede. Deur groot ideologiese bewegings en magtige mediamense word aangedring op universele aanvaarding van een standpunt en die totale verwerping van alle ander. Hierdie bedreiging van die mens se outentieke bestaan, individualiteit, vryheid en verantwoordelikheid het die gedagtes van groot denkers in ons eeu besig gehou. Ons gaan die insigte van enkeles van hulle oor dialogiese kommunikasie hier aanstip.

\subsection{Martin Buber}

Buber het die verdwyning van die dialoog in die omstandighede van ons eeu duidelik beskryf in sy boek / and Thou. Die mens van ons eeu se lewe draai vir 'n groot mate om die ervaring en gebruik van objekte, dinge. Op hierdie wyse ontstaan ' $n$ wanbalans in die mens se omgang met die dinge, en persoonlik met sy medemens. Die leefwêreld word verdeel in 'n dit-wêreld van die instellings, die openbare lewe, en 'n ek-wêreld van die gevoelens, die innerlike lewe. Die hedendaagse mens neig, met die oorwig van die dit-wêreld in sy/haar ervaring, om ' $n$ verarming te hê ten opsigte van persoonlike verhoudinge.

Om tot ware menslike bestaan te kom, moet die jy sentraal staan in die hede van die ek se lewe. In vandag se situasie verdwyn die jy. Die dialoog verdwyn. Die uitreiking na die jy in 'n ware ontmoeting verdwyn. Medemense word so dikwels as dinge, as objekte in ons moderne samelewing behandel.

'n Terugkeer tot die ware dialoog in ons omstandighede is moontlik indien mense doelbewus sou kies vir 'n uitreiking na die jy en 'n oorwinning van die skynbestaan. Daar moet egter geleenthede geskep word vir ontmoeting en gemeenskap tussen mense. In verband met ons onderwerp kan ons sê dat die Christelike geloofsgemeenskap, veral in die erediens, die geleentheid tot ontmoeting en egte dialoog skep.

Buber het ons bewus gemaak van die noodsaak van ontmoeting en 'n verhouding tussen mense binne 'n kommunikasiegemeen- 
skap. Hierbinne kan die dialoog ontvou. Hy het gewys op die noodsaak van ' $n$ eie selfstandige menslike bestaan in die onpersoonlike wêreld van ons tyd.

\subsection{Karl Jaspers}

Jaspers is in hierdie eeu saam met Martin Heidegger die grondleggers van die eksistensiefilosofie wat op Kierkegaard se gedagtes voortgebou het. Weer eens het ons hier met ' $n$ omvattende filosofiese sisteem te doen. Ons kan dus maar net raak aan dié gedagtes wat ons teorie voorthelp in sy ontplooiing.

Daar is egte en onegte kommunikasie wat saamhang met egte en onegte bestaan. Jaspers onderskei drie objektiewe kommunikasiewyses wat oneg is. Dit is kommunikasie wat in 'n naïewe gemeenskaplike bestaan, in ' $n$ intellektuele bestaan en in ' $n$ algemene bewussynsbestaan, geskied. Soos in Kierkegaard se onderskeidinge het ons hier ook met verskillende bestaanswyses te doen wat trapsgewys hoër opgaan. Hierdie drie bestaanswyses is egter nog nie eksistensiële bestaan (Existenz) nie. Die algemene bewussynsbestaan bring ons op die drumpel van die eksistensiële bestaan.

Die prikkel tot ' $n$ eksistensiële bestaan is, net soos by Heidegger, die gevoel van onvolkomenheid en onvergenoegdheid in ons wyses van bestaan en kommunikasie. Hierdie gevoel van tekortkoming of onbevrediging is die oorsprong van die deurbraak na "Existenz", die eksistensiële bestaan. Hierdie ervaring van onbevredigende kommunikasie lei tot 'n bestaansdeurligting (Existenzerhellung). So begin ek verstaan dat om myself te wees en te verwerklik ek 'n ander nodig het wat deur niemand vervang kan word nie. Vanuit myself kan ek nie kommunikeer nie kommunikasie is dialogies. In kommunikasie met die ander se self kom ons tot werklike syn, tot samesyn - ook as "Existenz". Dit is ' $n$ proses waarin ' $n$ verhouding ontstaan. Egte bestaan is ' $n$ verhouding tussen mense wat outentiek bestaan - dit is ' $n$ vérhouding tussen kommunikerendes. Onegte bestaan en kommunikasie is 'n hóding, téénoor die gespreksgenoot as voorwerp.

Plato het groot invloed op Jaspers uitgeoefen. Hy beskou Plato as die grootste denker in die geskiedenis. Sy gedagtes loop dus in die lyn wat ons tot hier gevolg het. Hy het ons insigte egter verdiep met sy verstaan van kommunikasie as ' $n$ verhouding waarin bestaansverwesenliking geskied. Jaspers het die feit van 'n kommunikasie deur ons bestaan op die voorgrond gebring. Dit gaan om die oordra van 'n boodskap wat outentiek is omdat dit in ons bestáán verwesenlik is. Hierdie tema, wat uiters belangrik vir geloofskommunikasie is, is verder uitgewerk deur 
Gadamer.

\subsection{H G Gadamer}

As ons in die buurt van die moderne hermeneutiese filosofie kom, besef ons dat kommunikasie nie net verbaal tussen gespreksgenote plaasvind nie, maar dat enige vorm van menslike uitdrukking kommunikeer wat deur die ontvanger vertolk moet word. Daar kan dus ' $n$ dialoog op gang kom tussen 'n ontvanger en 'n skildery, 'n geskrif, musiek - en die lewe self. Waar die hermeneutiek in die verlede hoofsaaklik op die verstaan van tekste (in die sin van geskrewe, oorgelewerde tekste) gekonsentreer het, is dit deur Heidegger en Gadamer verruim om ook ' $n$ vertolking van die lewe in te sluit. Hermeneutiek, as studie van die interpretasiehandeling self, maak ruimte vir 'n ontmoeting en dialoog tussen subjekte (interpreteerder én teks is subjektel.

Die vertolking van boodskappe is ' $n$ intersubjektiewe gebeure tussen mededeler en ontvanger, en die begrip wat gesoek word, gaan nie net om betekenis nie, maar om die bestaan self. Daarom kan $\mathrm{H}$ W Rossouw praat van die lewe as teks wat geinterpreteer word in ons soeke na die sin van die lewe.

Die hermeneutiek van Gadamer lê groot klem op die aktiewe rol van die ontvanger in die vertolking van boodskappe. Taal, in die breedste sin, is vir Gadamer die artikulering van die bestaan. Ons druk ons bestaan uit in kommunikasie en ons vind outentieke, sinvolle bestaan deur kommunikasie.

Wanneer ons 'n teks (geskrif, skildery, ens.) interpreteer, bestaan die interpretasie uit ' $n$ dialoog tussen verlede en hede. Hierdie dialoog is 'n konfrontasie waarin die interpreteerder in 'n aktiewe interaksie met die teks verkeer. Die aktiewe ontvanger moet sigself oopstel vir die teks, vrae aan die teks stel en verwag om deur die teks bevraagteken, gekritiseer, ontken of gewysig te kan word. Wanneer daar só 'n kommunikasie met die teks op gang kom, vind daar ' $n$ verstaansgebeure plaas, wat ' $n$ nuwe skepping is. Die boodskap van die teks bring die ontvanger tot 'n nuwe verstaan, tot begrip en tot 'n sinservaring.

Hierdie verstaansgebeure vind plaas deurdat daar 'n versmelting van horisonne plaasvind. Die verstaanshorison van die ontvanger (uitgangspunte, siening van sake, sosiale omstandighede, ens.) en dié van die teks versmelt, sodat daar ' $n$ intersubjektiewe verhouding ontstaan waarin twee leefwêrelde ontmoet, wedersydse begrip en 'n nuwe vertolking volg.

Uit 'n dialogiese ontmoeting met 'n lewenservaring volg daar begrip. Die begrip is moontlik omdat elke menslike uitdrukking lin welke 
vorm ook al) ' $n$ verbale artikulering van die bestaan is. Kommunikasie het dus te doen met bestaan - dit is bestaanskommunikasie. ' $n$ Waarheid word deel van ' $n$ mens se bestaan as jy dit deur kommunikasie ontdek. Wanneer jy so ' $n$ waarheid of ' $n$ boodskap aangaande die bestaan aan ander kommunikeer, plaas jy jou bestaan op die spel. Want ' $n$ lewenswaarheid wat sin maak, het deel van my bestaan geword, en wanneer ek dit oordra, doen ek dit deur my bestaan - deur die verbale artikulering van die bestaan, soos Brockelman dit stel. Hierdie insig is Gadamer se groot bydrae tot ons benadering in kommunikasie. Die evangelie moet eksistensieel deur jou kan gaan, dit moet geïnternaliseer word - dit moet die outentieke en sinvolle bestaan veroorsaak en stempel. Wanneer dit vanuit so ' $n$ bestaan gekommunikeer word, kan ontvangers uitgelok word om dieselfde bestaanswyse in hul lewens te realiseer.

\subsection{Jürgen Habermas}

Omdat ons met die dialogiese kommunikasieteorie ' $n$ ideale situasie wil beskryf waarna ons in ons kommunikatiewe handelinge in diens van die evangelie wil streef, is dit nodig om na die bydrae van Habermas in dié verband te kyk. Habermas staan in die tradisie van die kritiese teorie wat langs die hermeneuties-filosofiese skool in die Duitse filosofie loop. Hy het egter ' $n$ belangrike bydrae tot ons verstaan van kommunikasie gemaak.

'n Uiters belangrike komponent van Habermas se teorie is die ideaal van vrye mense wat sonder enige oorheersing waarlik met mekaar kommunikeer. Die grondliggende uitgangspunt, of "commitment" is dat die mens vry is en daarom geleentheid moet hê om sy/haar moontlikhede uit te druk en uit te leef. Hy noem hierdie ideale kommunikasie "Herrschaftsfreie Kommunikation". Dit gaan hier om 'n ideaal wat nêrens verwesenlik word nie, maar tog ook nie net ' $n$ wensdroom is nie. Dit is iets waarna ons verlangend uitsien in ons kommunikasie. Terwyl ons soek na onderlinge begrip, hoop ons om iets van die ideaal te verwesenlik. Uiteraard is mededelers en ontvangers volgens hierdie benadering op gelyke voet en vry om kommunikasiehandelinge te begin of te eindig. Elkeen kan vryelik deelneem. Die ideale gespreksituasie impliseer 'n onbegrensde kommunikasiegemeenskap. Die deelnemers aan hierdie kommunikasiegemeenskap veronderstel almal die ideale kommunikasiesituasie.

Uit die onderlinge begrip vloei ooreenstemming (Verständigung) voort wat ons beweeg tot handeling of aksie. Maar ook die aksie of praxis is kommunikatiewe handelinge om die situasie te verander in die rigting van die ideaal. Belangrik is dat "Verständigung", die onderlinge 
begrip of ooreenstemming, deur dialoog bereik word.

Habermas se begrip van "Herrschaftsfreie Kommunikation" in 'n ideale kommunikasie-situasie is deur praktiese teoloë soos Rolf Zerfass, Helmut Peukert en Ernest Henau vertaal in die ideale kommunikasiesituasie wat deur die teologiese begrip "koninkryk van God" geskep word. Binne die geloofsgemeenskap van Christene kan hierdie ideaal funksioneer. Daar kan dan volgens koninkrykswaardes gekommunikeer word, met die doel om die geloof op sy beurt te kommunikeer, sodat die koninkryk kan kom in die lewens van mense en die gemeenskap. Kommunikasie volgens koninkrykswaardes binne die ideaal van die gekome en komende koninkryk van God, verskaf 'n sterk onderbou aan ons teorie van dialogiese kommunikasie as ideaal vir die praxis van kommunikatiewe handelinge in diens van die evangelie.

\subsection{Marthinus van Schoor se dialogiese kommunikasieteorie}

Van Schoor se dialogiese teorie van kommunikasie is gebou op Plato se teorie en praktyk van die dialoog. Kierkegaard se insigte, en die mensbeskouing van Ortega y Gasset, speel 'n groot rol in Van Schoor se teorie.

Van Schoor se model is opgebou rondom die drieluik van mededeler, boodskap en vertolker. Tussen die aktiwiteit van mededeler en vertolker is daar nie veel verskil nie. Die mededeler is die beginpunt van die boodskapverkeer. Kommunikasie is immers volgens Van Schoor die tussenmenslike verkeer van die mededeling en vertolking van boodskappe. Die vertolker is nie die eindpunt nie (hy/sy is geen ontvánger nie, maar vertólker), maar die kéérpunt van die boodskapverkeer. Sodoende word die mededeler vertolker en die vertolker weer mededeler. Vertolking is ' $n$ volghandeling waarin die vertolker die mededeler in sy voetstappe volg, nie uiterlik nie, maar inwendig. Die vertolker verstaan die boodskap in ' $n$ mededeling in die mate wat hy/sy in staat is om die mededeling na te boots. Deur die ruimte vir 'n heen-en-weer tussen gespreksgenote ontvou die dialoog. Die kommunikeerders is op gelyke voet en is vry om selfstandig die boodskap te vertolk en mee te deel en elk tot eie gevolgtrekkings te kom.

Dit is egter so dat die mens ' $n$ behoefte het om mee te deel en boodskappe te vertolk. Die doel is om tot verstaan, tot begrip en tot onderlinge begrip te kom. Dit dra by tot die geluk van die mens. Uiteindelik raak dit ook die syn van die mens. Die sin van kommunikasie is dus volgens Van Schoor intersubjektiwiteit en onderlinge begrip.

Die bedoeling is dat hierdie kommunikasie ook in groter groepe as tussen twee mense kan plaasvind en dat daar ruimte is vir die inag- 
neming van die sosiale, ekonomiese, politieke, persoonlike en ander omstandighede en vir die verskillende media van kommunikasie naas taal.

\section{Slot}

Vir die kommunikatiewe handelinge in diens van die evangelie waarmee ons vak besig is, pas die dialogiese kommunikasieteorie die beste by die aard en gees van die evangelie. Daarom kan dit die kommunikasie van die evangelie ook die beste dien. Ons sou die elemente en insigte wat hierbo belig is in die denkpatrone van verskeie denkers oor kommunikasie deur die eeue, as die grondlyne vir ons teorie kon aanvaar. Hul gedagtes is só weergegee dat daar algaande ' $n$ verdiepende en ' $n$ breër perspektief op die teorie kronologies vir die leser geopen is. Ons sou verder steeds vanuit ons vak se perspektief aan hierdie teorie kon skaaf en verfyn.

Die grondliggende tendens in die oorsig wat ons gegee het, is dat die kommunikasie intermenslik is; in vryheid en op gelyke voet geskied; dat onderlinge begrip ontstaan deur die deel, die meedeel en vertolking van die evangelie; en dat dit bestaanskommunikasie is. Bestaanskommunikasie beteken dat ons deur die vertolking en aanvaarding van die goeie boodskap ons bestemming as mense vind. Dit beteken ook dat ons dit oordra aan ander met ons hele bestaan as waarborg daarvan. En dit beteken dat ons uit hierdie boodskap leef - en nie anders kan of wil nie.

Binne die konteks van die koninkryk van God as ideale kommunikasie-situasie, dien die dialogiese kommunikasieteorie as die ideaal waarvolgens ons ons Christelike kommunikasie behoort in te rig. Op hierdie wyse funksioneer dit as 'n kritiese teorie vir die wetenskaplike ondersoek van die kommunikasiepraktyk van die bediening.

\section{LITERATUURLYS}

A Augustinus, Belÿdenisse (vertaal deur G Wÿdeveld). Amsterdam 1981.

C Baümler, Kommunikative Gemeindepraxis, München 1984.

$\mathrm{P} \mathrm{T}$ Brockelman, Existence and the world of ordinary experience. An introduction, Washington 1950.

M Buber, I and Thou, New York 1970.

J M Cronje \& J A van Wyk, Van mens tot mens. Kerklike kommunikasie in teorie en praktyk, Pretoria 1982.

P S Dreyer, Die wysbegeerte van die Grieke, Pretoria 1976.

G Fauconnier, Aspects of the theor of communication, Pretoria 1985.

J Firet, Spreken als een leerling. Praktisch-theologische opstellen, Kampen 1987.

H G Gadamer, Truth and method, New York 1975. 
J Habermas, Theorie der kommunikativen Handeln, Bd I \& II. Frankfurt 1982.

E Henau, "Schriftinterpretatie als element van kommunikatie", Praktische Theologie vol 4 (1986), 87- 101.

N Jansen, "Soren Kierkegaard: Haltes op die lewenspad", Communicatio vol 12/2 (1986), 2-8.

K Jaspers, Philosophy, vol 2 Chicago 1970.

$\mathrm{H}$ Koningsveld en J Mertens, Communicatief en strategisch handelen. Inleiding tot de handelingstheorie van Habermas, Muiderberg 1986.

S W Littlejohn, Theories of human communication, Columbus 1978.

O Noordmans, Augustinus, Haarlem 1952.

H Peukert, Wissenschaftstheorie - Handlungstheorie - fundamentele Theologie. Analysen zu Ansatz und Status theologischer Theoriebildung, Düsseldorf 1976.

H J C Pieterse, Die Woord in die werklikheid. 'n Teologie van die prediking, Pretoria 1988.

H W Rossouw, Die sin van die lewe, Kaapstad 1981.

$M$ van Schoor, Wat is kommunikasie? Pretoria 1986.

J A Wolfaardt, Kommunikatiewe handelinge, Intreerede, Universiteit van Suid-Afrika 1987. 